\title{
KOMUNIKAT KONGREGACJI KULTU BOŻEGO I DYSCYPLINY SAKRAMENTÓW
}

$\mathrm{Z}$ wielu stron i z różnych miejscowości nadeszło do tej Kongregacji Kultu Bożego i Dyscypliny Sakramentów następujące pytanie: „Czy biskupi mogą nosić krzyż na piersiach także na ornacie?” Odpowiedź: Twierdząca.

Zwyczaj noszenia przez biskupów krzyża na piersiach na ornacie w czasie celebracji eucharystycznych, który jest cechą charakterystyczną obrządku ambrozjańskiego oraz liturgii wschodnich, w ostatnich latach rozpowszechnił się także w liturgii rzymskiej. Wydaje się, że jest właściwe, aby biskup, zarówno wtedy gdy odprawia sam, jak i wtedy gdy przewodniczy koncelebrze, mógł mieć znak, który odróżnia go od prezbiterów. Dlatego ta Kongregacja, w dodatku do dotychczasowych przepisów postanawia, za zgodą Wyższej Władzy, że krzyż może być noszony także na ornacie, pozostawia się jednak możliwość noszenia krzyża pod ornatem, według uznania biskupa.

Rzym, 16 lipca 1997.

+ JORGE MEDINA ESTEVEZ

Arcybiskup Pro-Prefekt

+ GERALDO M. AGNELO

Arcybiskup Sekretarz

\begin{tabular}{lllllllll}
$N$ & $E$ & $K$ & $R$ & $O$ & $L$ & $O$ & $G$ & I \\
\hline
\end{tabular}

\section{O. Franciszek Małaczyński OSB}

\section{Ś.P. O. JORGE PINELL OSB (1921-1997)}

8 stycznia 1997 roku zmarł w Opactwie Najświętszej Maryi Panny w Montserrat o. Jorge Pinell, długoletni profesor Papieskiego Instytutu Liturgicznego w Rzymie. O. Pinell urodził się w Barcelonie 17 maja 1921 roku 
i na chrzcie otrzymał imię Jan. Od młodości interesował się literaturą grecką, łacińską i katalońską. W roku 1946 wstąpił do Opactwa Montserrat i otrzymał imię zakonne Jorge (Jerzy). Śluby wieczyste złożył 15 sierpnia 1950, a święcenia kapłańskie otrzymał 30 sierpnia 1953. W czasie studiów teologicznych zainteresował się szczególnie liturgią i już jako diakon opublikował artykuł o modlitwach o pokój w Sakramentarzu św. Leona. Po święceniach kapłańskich zainteresowania o. Pinella zwróciły się ku liturgii starohiszpańskiej, zwanej mozarabską. Od roku 1954 ukazywały się jego artykuły na temat liturgii hiszpańskiej. Gdy powstawał Papieski Instytut Liturgiczny w Rzymie, o. Pinell został powołany w skład jego wykładowców i rozpoczął wykłady od kursu o liturgii hiszpańsko-wizygockiej i gallikańskiej. Oprócz hiszpańskiej liturgii mszalnej o. Pinell interesował się Liturgią godzin oraz krytyką tekstów liturgicznych. W roku 1971 ukazal się jego Liber Orationum Psalmographus. Ta książka jest hipotetyczną rekonstrukcją hiszpańskiej księgi liturgicznej, opartą na średniowiecznych rękopisach. Oprócz tekstów liturgicznych zawiera krytyczne wydanie tekstów psalmów używanych w liturgii hiszpańskiej. O Pinell wychował cały szereg specjalistów liturgii hiszpańskiej jako promotor ich prac licencjackich i doktorskich. Nie opuszczając wykładów w Rzymie o. Pinell przez wiele lat wykładał w Instytucie Liturgii Pastoralnej w Padwie. Po Soborze Watykańskim II był konsultorem Komisji pracujących nad rewizją Liturgii Godzin.

Dnia 12 lipca 1982 roku arcybiskup Toledo kardynał Marcello González Martin mianowal o. Pinella przewodniczącym Komisji powołanej do zreformowania liturgii hiszpańskiej w duchu Soboru Watykańskiego II. W skład Komisji weszło wielu słuchaczy o. Pinella. W roku 1991 ukazała się pierwsza część Missale Hispano-Mozarabicum. Wprowadzenie i obrzędy Mszy są dziełem o. Pinella. W roku 1992 z okazji 70-lecia wydano na cześć o. Pinella pracę zbiorową pt. Psallendum. Zawiera ona pełną bibliografię książek i artykułów wybitnego liturgisty.

W ostatnich latach życia o. Pinell uczestniczył w Męce Chrystusa przez ciężką chorobę. Ufamy, że uczestniczy także w Jego chwale.

Kraków-Tyniec

O. FRANCISZEK MAEACZYŃSKI OSB

Ks. Jerzy Chmiel

\section{ŚP. KS. JOSEF SCHARBERT (1919-1998)}

Po długiej chorobie zmarł ks. Josef Scharbert, profesor biblistyki Starego Testamentu we Freising i Monachium.

Pochodził z rodziny Niemców sudeckich, ziemi dziś należącej do Czech. Ukończył gimnazjum we Freudenthal i rozpoczął studia teologiczne w Philosophische-Theologische Hochschule w Widnawie (Weidenau), która to uczel- 